Summer 6-1-2013

\title{
Women Who Kill: An Analysis of Cases in Late Eighteenth- and Early Nineteenth-Century London
}

Kathy Callahan

Murray State University, kcallahan@murraystate.edu

Follow this and additional works at: https://digitalcommons.murraystate.edu/faculty

Part of the European History Commons

\section{Recommended Citation}

This is a peer-reviewed article published by Journal of Social History (ISSN: 1051-144X) on June 1, 2013, available online: https://doi.org/10.1093/jsh/sht004

This Peer Reviewed/Refereed Publication is brought to you for free and open access by Murray State's Digital Commons. It has been accepted for inclusion in Faculty \& Staff Research and Creative Activity by an authorized administrator of Murray State's Digital Commons. For more information, please contact msu.digitalcommons@murraystate.edu. 


\title{
Section IV: Regional Themes
}

\author{
Kathy Callahan
}

\section{Women Who Kill: An Analysis of Cases in Late Eighteenth- and Early Nineteenth-Century London}

\begin{abstract}
In late eighteenth-and early nineteenth-century London, the number of women prosecuted for murder was quite small with only forty women reaching the felony court at the Old Bailey for trial between 1783 and 1815. Despite the small number of prosecutions, the cases do reveal important information about gender and criminal justice. Accusations demonstrate difficulties women had with a wide range of interpersonal relationships, their lives in the city, in addition to domestic and substance abuse. Sentencing patterns, too, are illuminating. For those women found guilty, the courts often hesitated to convict to the fullest extent of the law. Juries and judges presiding in homicide cases in London regularly employed discretion when making their decisions, demonstrating that they apparently heavily weighed numerous personal factors presented in trial. While the law gave judges substantial leeway in capital case sentencing, juries and judges focused their full convictions and harshest penalties, capital punishment, on women who violated important gender-based behavioral expectations.
\end{abstract}

When Maria Theresa Phipoe (alias Mary Benson) approached the gallows at Newgate jail on December 10, 1797, the Times reported that crowds gathered to witness her execution "was numerous almost beyond example." Atop the scaffold, Phipoe addressed the multitude, a custom at executions, telling them that she believed her sentence just and ascribed her "frequent gusts of passion" to her "use of laudanum." As those assembled listened, it is unknown whether they stopped long to think about Phipoe-as a person or as a criminal; they had, after all, come to take in the spectacle of a hanging, not contemplate eighteenth-century criminality. ${ }^{2}$ The jury found Phipoe guilty of inflicting mortal stab wounds upon her friend, Mary Cox, during an argument over the purchase of a watch. ${ }^{3}$ Little doubt of her guilt existed as she, bloody and injured, confessed to authorities at the scene saying, "I believe the devil and passion bewitched me."4

Few women faced charges for violent crimes in England in the decades around 1800. In London, for example, less than 1 percent of the women who faced trial at the London and Middlesex felony courts held at the Old Bailey did so for violent crimes. Female criminality, writes John Beattie, provides historians

Journal of Social History vol. 46 no. 4 (2013), pp. 1013-1038

doi: $10.1093 /$ jsh/sht004

(C) The Author 2013. Published by Oxford University Press. All rights reserved.

For permissions, please e-mail: journals.permissions@oup.com. 
with an indicator of women's "relationship to the wider community." Despite the small number of accusations against women, prosecutions for violent crimes do reveal important evidence about women and their lives in the metropolis. For example, the trial narratives of women indicted for murder tell the stories of interpersonal relationships gone awry, domestic violence, substance abuse (as Phipoe demonstrates), as well as the movement of women around the city. Convictions and sentencing reveal illuminating information about women in the metropolis as well. Similar to Peter King's findings on property crimes and the employment of discretion at all levels of justice, juries and judges presiding in murder cases at London's felony courts also regularly employed discretion. ${ }^{6}$ For those women found guilty, the courts often hesitated to convict many to the fullest extent of the law, demonstrating that they apparently heavily weighed numerous personal factors when making conviction and sentencing decisions including marital status, work and age.

This study emanates from my larger work on female criminality in London between the years 1783 to 1815 , a period during which approximately 8,000 women faced trial for a wide range of offences, almost exclusively property crimes. ${ }^{7}$ Eighteenth-century property crimes have been examined extensively by historians of crime including, for example, John Beattie, Peter King, and Deirdre Palk. ${ }^{8}$ One point that historians of the period argue nearly universally is that economic necessity often motivated property crimes. ${ }^{9}$ Motivations for crimes against other persons, however, are not as easily explained but most focus on problematic relationships.

The period itself, 1783 to 1815 , is one that has often escaped attention by historians of crime. They have tended to focus their attention on the 1700 s and have largely ignored the end of the long eighteenth century focusing instead on the Victorian era and the change of policing and the criminal codes that occurred during that period. This thirty-two-year period is treated as one continuous era as it extends from the end of one war through the end of another, including periods of peace, and these political activities had important ramifications for women. ${ }^{10}$ During wartime women often found themselves on their own as men served in the military and during peace women had greater difficulty finding work.

The examination of this period contributes to the study of women and murder in the metropolis in several ways. First, it expands on previous writings on the eighteenth century by providing greater detail about women accused of murder and related charges. Second, it fills a void in the study of early nineteenthcentury female criminality. Finally, the study also demonstrates that King's argument about discretionary justice and its application to property crimes has some application to murder cases as well. While discretion likely did not play a role in prosecutions, it was important to the process of conviction and sentencing. The Old Bailey Sessions Proceedings (known henceforth as OBSP) and Home Office documents including the Sheriffs' of Newgate Calendars provide the basis for analysis. ${ }^{11}$ The Old Bailey was the site of London's felony trials where cases from both the County of Middlesex and the City of London were held. The OBSP were narratives of the trials published in London. Newgate jail sat adjacent to the Old Bailey; most defendants awaited trial there as few individuals posted bail or were released on their own recognizance. Each month the sheriffs recorded the names of those remaining at the jail as well as those recently admitted. 
Table 1. Female Indictments for Violent Crimes Heard at Old Bailey, 1782-1815

\begin{tabular}{lcr}
\hline & Number & Percent \\
\hline petit treason & 1 & 1.3 \\
willful murder and attempted murder & 37 & 49.4 \\
manslaughter & 1 & 1.3 \\
aiding and abetting murder & 1 & 1.3 \\
infanticide & 24 & 32.0 \\
misc. violent crimes & 11 & 14.7 \\
TOTALS & 75 & 100 \\
\hline
\end{tabular}

Source: OBSP, Dec. 1782-Nov. 1815.

Over the 32-year period under examination, the coroners and grand juries indicted 75 women for acts of felonious violence (Table 1). Violence continued to be a part of everyday life in eighteenth-century London. War was nearly constant, people lost their lives at work or on the streets and fights between individuals occurred regularly. Yet, the felony courts did not hear many cases involving violent behavior. ${ }^{12}$ Many more men were charged with violent crimes than were women. Men faced charges for violent crimes in a total of 581 prosecutions, representing 2.5 percent of all male indictments, an average of 30 per year. ${ }^{13}$ This compares to 75 indictments or 1 percent of all female indictments. With a metropolitan population of approximately one million persons, this number is quite low, averaging fewer than three per year. ${ }^{14}$ One-third of these were for infanticide, a crime that has been well studied. ${ }^{15}$ About half of the indictments were for willful murder and related offences; it is these crimes that are the focus of this article.

The gender difference in terms of indictments for violence revealed by these numbers fits with other recent analyses of gender and crime in early modern and modern Europe. ${ }^{16}$ Julius Ruff theorizes that eighteenth-century society had little interest in female violence. ${ }^{17}$ Evidence from indictments, verdicts, and sentencing in property crimes suggests that society did not feel threatened by female transgressions and those feelings may have also translated into fewer indictments for violent crimes. ${ }^{18}$ Furthermore, some men may have not reported female-perpetrated violent crimes as this might have impugned their masculinity. ${ }^{19}$ Another possible reason for a lower number of female indictments is that women may have relied on men to help them protect possessions or personal honor thus putting those men, not themselves, in defensive situations. In late eighteenth-century society, men readily acted to protect their own honor which often led to altercations. ${ }^{20}$ Men also trained for violence in ways women did not. Robert Shoemaker argues "for boys, fighting was a form of play," no matter what their socio-economic class. This instruction extended into adulthood as men trained for self-defense and the military. Such education, Shoemaker suggests, formed the foundation of "accepted codes of masculine behavior and . . . affirm[ed] their gender identity." 21

Because of the number of men accused each year, coupled with the fact people expected men to be violent, historians have tended to focus on male offenders. Other than cases of infanticide, they have not deeply studied the individual circumstances that brought women to court for murder or the reasoning behind verdicts. $^{22}$ Clive Emsley's Hard Men: Violence in England Since 1750 
serves as a cogent example of recent focus on male perpetrators. ${ }^{23}$ Several studies explore domestic violence, but they largely analyze violence perpetrated by men against women, not that perpetrated by women. ${ }^{24}$

Some examination of female violence does appear in several general works and in some that focus on punishment. For example, Beattie's work Crime and the Courts in England includes information about violent females as do monographs on punishment such as The Hanging Tree, The London Hanged and Convict Maids. ${ }^{25}$ In a recent work, Victims and Viragos, Gregory Durston provides a more detailed examination of female violence in the eighteenth century than any other work to date. He agrees that the literature has largely ignored female commission of homicide, concluding that females were not always held to the same standards for indictment and conviction as were males. His work on murder does not, however, probe deeply into the lives of individual women as a means to understand the circumstances that contributed to capital convictions, nor does he examine years beyond $1800 .{ }^{26}$ Carolyn Conley addresses homicide in Certain Other Countries, and she concludes that judges and juries of England, Ireland, Wales and Scotland, after the Acts of Union, demonstrated important regional differences related to indictment, conviction and punishment of defendants and that gender, ethnicity and class were key components in those differences. Her analysis is limited to the late nineteenth century, however, as is that of other works. ${ }^{27}$ The early years of the century have largely escaped consideration and major changes in law and policing after 1829 makes direct comparison with the Victorian era problematic. This article seeks to add to existing studies, illuminating the backgrounds of defendants, in this study exclusively working class defendants, and the circumstances of their cases as well as provide a more thorough explanation of the capital convictions and the use of discretion by the courts.

Women in London enjoyed some freedoms in the metropolis, regularly moving about the city for work or family obligations. Social convention, however, did restrict them in a variety of ways. Societal expectations called for a woman to be under the protection of a man whether it be a father, husband (or partner), or master, thus keeping them from being truly independent. Working-class women faced particular challenges. Their work paid low wages in an effort to preserve society's patriarchal structure, forcing them to marry or, if single, attempt to find work that gave them a semblance of protection. ${ }^{28}$ Hundreds of females migrated into London on an annual basis to find work, usually as servants; during the eighteenth century domestic service increasingly was a female occupation. Other women took jobs as needleworkers, some odd jobs, and still others resorted to prostitution. Living in as a servant provided two important things: protection of an employer and, at a minimum, subsistence living. With those provisions, servants and masters maintained a tenuous relationship. On one hand, servants were virtually family members; on the other hand, a number of laws dictated their subservient position. ${ }^{29}$ Prostitutes found their place to be particularly problematic. Their work had been disdained for centuries but they also thumbed their nose at convention by living alone or with other women. In court narratives, these two occupations played a prominent role, including those for murder.

Murder, according to Clive Emsley, "is probably among the most frequently reported offenses," yet homicide prosecutions still reached the courts in only a small fraction of the actual incidents in the period under study here. When an 
unnatural death occurred, the coroner investigated, but very often no perpetrator could be identified. ${ }^{30}$ Investigators had difficulty unearthing evidence in these crimes, so much so that the courts recognized circumstantial evidence might be all the jury had to work with to reach their decisions. A Mr. Gurney, attorney for the prosecution in the trial for the murder of George Hebner in 1796, argued:

[S]uch is the nature of the crime of murder, that it is perhaps more than any other perpetrated in secret. ... It is therefore but seldom that the direct testimony of eye-witnesses can be obtained, another species of evidence is of course necessarily resorted to, in general, which is in many cases not less satisfactory, in some unquestionably still more satisfactory than the positive testimony of eye-witnesses. Evidence of a number of circumstances, which like so many links of a chain each in itself, perhaps but of little importance, yet when combined together forming such a regular and unbroken series as conduct the human mind to an unerring conclusion. ${ }^{31}$

The range of laws covering the death of another person gave coroners and grand juries several options when writing indictments. Juries and court officials could decide on a case-by-case basis under which statute a person would be charged; ${ }^{32}$ one might argue that discretion was built into the law code. In London, indictments for willful murder proved to be the most prevalent charge for both women and men. Individuals could also be charged with justifiable homicide or manslaughter. Murder and attempted murder charges differed from manslaughter charges in important ways. The former required some proof of planning, while the latter suggested the perpetrator acted without premeditation. Beattie asserts that grand juries purposefully used the willful murder charge to force a defendant to "explain the circumstances that led to the victim's death." Trial juries could then downgrade the charges after hearing testimony, if appropriate. ${ }^{33}$ In very rare cases, a woman might be charged with petit (petty) treason in addition to murder because she allegedly killed her husband. About this law, William Blackstone writes, "petit treason, according to the statute 25 Edw. III. c2. may happen three ways: by as servant killing his master, a wife her husband, or an ecclesiastical person his superior to whom he owes faith and obedience." ${ }^{44}$ "Obedience," of course, sums up the behavioral expectations of servants and women in one word.

Throughout the eighteenth century, murder indictments declined in England. In London, the numbers dropped dramatically from "25.8 cases per hundred thousand people" in the early years of the century to "10.8 cases per hundred thousand" by $1775 .{ }^{35}$ Surrey and Sussex, too, had fewer indictments over the course of the century. A combination of fewer actual murders, new definitions of murder and a changing concept of male honor may have led to the decline. $^{36}$ Despite, or perhaps because of, their declining frequency, murder trials fascinated the public and many attended. Individuals also had access to trials through many printed sources, including the OBSP, the Times and other newspapers, as well as prisoner-penned memoirs. ${ }^{37}$

During the period under study here, 36 deaths led to the prosecution of 40 women. The courts charged the women with five different homicide-related offenses, four of them capital: petit treason (one woman), homicide (35 women), aiding and abetting murder (one), and attempted homicide (two). 
In England in this period capital punishment, for the vast majority of the population, meant hanging. ${ }^{38}$ Beginning in November 1783, London's capital convicts were hanged outside of Newgate jail; before that date executions took place at Tyburn on London's west side. Only one woman in this study, Elizabeth Everton, faced charges for the non-capital offense of manslaughter. ${ }^{39}$

The homicide accusations against women in London were different than those against men. First, the courts indicted far fewer women; while 40 women were indicted, over eight times the number of men-308-faced similar charges. ${ }^{40}$ Second, the weapons used by the two sexes often differed. Knives were common for women, though one woman used a bayonet and two others employed forks. In most situations, women killed with weapons within reach. ${ }^{41}$ Men also used knives, but swords and guns as well. Third, indictments for murder by men sometimes emerged in the course of other actions. Henry Morgan and Alexander Dixon, for example, were charged with murdering Charles Linton during a robbery attempt. ${ }^{42}$ Men occasionally faced homicide charges when dueling or engaging in athletic contests to save face or settle disputes resulted in a death. ${ }^{43}$ By contrast, no woman was charged with murder committed during the execution of another offense nor did any respond to verbal threats with murder. Fourth, no grand jury or coroner indicted a woman for killing an employee, while several men were accused of killing their apprentices or servants. ${ }^{44}$ Employers had sanctioned authority to correct anyone in their household, and it is not surprising that they sometimes inflicted injury severe enough to cause death. ${ }^{45}$

\section{Profile of Defendents}

Developing a profile of women accused of crime challenges historians because of inadequate sources. Information recorded in each collection represents what the author felt important. Sheriffs kept incomplete records and courtroom reporters sometimes failed to record demographic information. Furthermore, unless the trial was lengthy or contained sordid details, what was included for publication in OBSP could be quite brief as the following shows:

ELIZABETH-ANN MOSS alias HOLMES was indicted for the willful murder of George Holmes, on the $1^{\text {st }}$ of March. There being no evidence against the prisoner, she was ACQUITTED. ${ }^{46}$

Existing sources show that most of the women in London's felony court were tried for property crimes. They tended to be young, unmarried, and from outside of London; if employed, they most likely engaged in domestic service or prostitution.

Women accused of murder present a different profile. Although sources are thin, the highly personal nature of homicide opened the lives of the accused to public inspection in ways quite different from property crimes. Court narratives and the Sheriffs' Calendars provide information on age and place of birth of 24 of the 40 women accused. (Table 2) Women indicted for homicide tended to be older than those indicted for property crimes. ${ }^{47}$ This might represent a real difference in the age of the perpetrators. It might also be the result of the authorities choosing not to prosecute women in their late twenties through their 
Table 2. Available Age Distribution for Women Indicted for Murder and Related Crimes

\begin{tabular}{lc}
\hline Ages & Number \\
\hline $10-14$ & 1 \\
$15-19$ & 2 \\
$20-24$ & 6 \\
$25-29$ & 2 \\
$30-34$ & 5 \\
$35-39$ & 3 \\
$40-44$ & 1 \\
$45-49$ & 3 \\
$50-55$ & 1 \\
missing & 16 \\
TOTAL & 40 \\
\hline
\end{tabular}

Source: OBSP and National Archives, Sheriffs' Calendars, HO 26/1 - 26/21.

early forties who were probably underrepresented among those prosecuted for property crimes. At this age many women had children; victims and magistrates alike may have felt sympathetic to the plight of many of these women in trouble with the law and employed discretion by choosing not to prosecute. Such prosecutorial discretion did not extend to murder. ${ }^{48}$

People in London were often suspicious of persons from outside of the metropolis, particularly foreigners, so place of birth may have played a role in indictments for property crimes. ${ }^{49}$ Such prejudices had less influence in murder cases because of the heinous nature of the crime itself..$^{50}$ Recorded birthplace information exists for eight women: three came from metropolitan London, four from Ireland, and one from Sussex. Negative comments about a woman's place of birth occurred in only one trial involving two Irish women celebrating Christmas by drinking and dancing at a public house. A Mr. Gurney, attorney for three of the eight Irish defendants, posed the following question to a Bow Street Runner on the witness stand: "You know that is a day [sic December 26] upon which the lower sort of Irish always meet for the purpose of merriment?"'1 Several other women also bore Irish surnames but no significant comments about their places of birth occur in the testimony.

Narratives in OBSP prove more informative regarding marital status. Defendant and witness testimony suggests that eight of the 40 accused women were married and five were in domestic partnerships. The law allowed married and cohabiting women to claim marital coercion in many types of cases, though not homicide, which may account for the higher percentage of partnered women standing trial for murder than for property offenses. ${ }^{52}$

The trial narratives of 15 of the 40 women (38 percent of those accused) contained employment information, a percentage significantly higher than for women accused of all crimes (28.5 percent). ${ }^{53}$ Two factors likely explain this: first, we know more detail about the murder cases and, second, work and homicide often went hand-in-hand. As a result, court reporters included employment information because of its relevance to the crime under investigation. Five prostitutes, four servants and six women employed in miscellaneous positions stood trial for homicide and related offenses. 
Table 3. Relationship of Indicted Females to Deceased

\begin{tabular}{lr}
\hline & Number \\
\hline husband/lover & 5 \\
children in family & 5 \\
other family members & 2 \\
friends/neighbors & 11 \\
known through work & 7 \\
strangers & 4 \\
other* & 2 \\
no information & 4 \\
Total & 40 \\
\hline
\end{tabular}

Source: OBSP, Dec. 1782-Nov.1815.

*'Other' category includes a woman charged with aiding and abetting the murder of a newborn infant and the miscarriage/death of a fetus as the result of an altercation in which its mother later died.

The demographic information available for women accused of murder reveals more about the selective application of the law than anything else. The women accused of murder differed from those accused of all crimes, but some of this difference resulted from the fact that many women in child-bearing years evaded charges for property crimes because of sympathy for family hardship, and others because of the long-supported principle of marital coercion. Additional demographic information such as place of birth and occupation is known because there was simply more testimony in murder trials, not because these were unusually important.

\section{Allegations and Trials}

Women's lives most often revolved around their homes and the activities required to sustain themselves and their families. Following this pattern, women charged with murder in London tended to be charged with killing those with whom they interacted regularly (Table 3 ). Testimony given at the Old Bailey revealed charges filed for killing relatives including husbands, lovers and children, as well as friends, neighbors and persons known through work. Stranger murder proved, in fact, quite rare. ${ }^{54}$

These cases thus fit the pattern of "domestic homicide" identified by J. A. Sharpe. Beattie and Garthine Walker also found that women generally faced charges for "killing someone within their domestic circle or at least in their neighborhood." ${ }^{55}$ Property cases sometimes revealed the wretchedness of the human condition, and homicide cases often showed humanity in an even more miserable light. These cases tell the stories of discord, substance abuse, accidents, and emotions run amuck, and also provide evidence about the strained conditions under which many Londoners lived.

In cases involving women who allegedly killed their husbands, charges of petit treason could be included along with, or instead of, charges for willful murder. Until the statute changed in 1790 , women found guilty of petit treason faced the possible sentence of burning at the stake. ${ }^{56}$ In the cases examined 
here, one legally married woman faced charges for killing her spouse, although she did not face petit treason charges. The courts indicted Honour Brown for her husband Stephen's death after a servant found him hanged in an upstairs room. Honour and her witnesses, including the servant who found the body, convinced the court that Stephen took his own life. Honour's work as a prostitute figured into their marital problems and his apparent despondency, according to witness testimony. The day of his death, the couple quarreled about Honour's clients. Afterwards, Honour began packing, readying to leave her husband. Servant Elizabeth Andrews testified: "Mrs. Brown and he had some words . . . I did not hear what passed; Mrs. Brown said, I believe, she would not have any of her friends insulted, while he, the husband, lived upon the prostitution of her body." 57

Other cases against co-habitants also provide information about troubled relationships, including spousal abuse, often perpetrated by both parties. For example, Sarah Puryer faced charges for murdering her brother-in-law and lover, John. During an alcohol-fueled altercation, Sarah allegedly hit him with a mallet. A witness testified, "They were very unhappy, they frequently quarreled. . . . ${ }^{58}$ In another case, Mary Ann Winter (otherwise Stone) stood trial for the death of her lover, Abe Winter. Their final fight took place in a public house where Abe insulted and then attacked Mary Ann, hitting her in the face with his fist. Testimony given by Elizabeth Ernsby revealed that Mary Ann had been subjected often to physical abuse by her live-in partner. As Elizabeth told the court about the night of the killing, she recalled the following: "She [MaryAnn] cried to me upon the ill usage he gave her; I said, I would not stay with him; she then said, she would not stay with him, that on Friday evening, he came and used her very ill, broke and destroyed all she had . . .; she shewed [sic] me her left hand, it was very much swelled."59 At all socio-economic levels husbands and wives engaged in spousal abuse; that homicides sometimes resulted is not surprising. It is also not surprising that women were more often the victims of domestic homicide than were men. 60

Several children allegedly lost their lives at the hands of women. Coroners and grand juries charged five women in the deaths of their own children and one, Sarah Smith, in the death of the child of her lover Rueben Main. The couple faced charges for killing ten-year-old Rueben Main, Jr., after the boy died in a fire at the brickyard where the three of them lived and worked. Main was tried because he had threatened to burn down the establishment the day of the fire. There is no clear indication to why Smith was indicted except for the fact the two lived together. ${ }^{61}$ In a similar incident, Elizabeth Lovedon and her partner, Thomas Masters, allegedly killed Lovedon's six-year-old daughter, Mary. Masters confessed in a written statement that he had beaten the girl in her mother's absence, resulting in Lovedon's eventual exoneration. ${ }^{62}$ Only one instance of a married woman tried for killing a newborn went to trial in the late eighteenth century. She could not be charged under the infanticide statute because that statute was aimed specifically at the prosecution of single women. In this 1788 case, Rachel Harmer, wife of John, stood accused of killing her newborn child. Edmund Goddard, out for a walk with his dog, found the child dead in a pond near Harmer's home. Elizabeth Willowby, allegedly helped with the delivery and disposal of the corpse; she faced charges for aiding and abetting the murder. ${ }^{63}$ 
In another heart-wrenching case, Sarah Evans was charged with the death of her four-year-old son, George, whom Charles Baldwin found laying on the banks of New River. Sarah defended herself saying she had delivered the boy, on the order of George's father, Thomas Aris, to a woman who was to take him "to the country." Aris did not want to support George or the other two children he fathered with Sarah. Sarah first encountered Aris while living in the poorhouse and felt she had no choice but to do as Aris had ordered. ${ }^{64}$ Hannah Champion was also charged with the murder of her child. The five-week-old illegitimate boy drowned when left unattended in a bathing tub. Strange events surrounded the child's death. Neighbors and the defendant alike reported a distraught stranger going house to house, looking for his child. He allegedly took the baby from Sarah, said he would kill the child, and fled. In summation, Judge Lloyd Lord Kenyon offered the following words to the jury regarding the defendant:

This indictment charges the prisoner with the greatest offence that can be committed by a human being, under the aggravated circumstances of the object of it being a poor unprotected child, the fruit of her own body, when it had no power to struggle for the preservation of its own existence . . 65

The largest single category of indictments involved women allegedly killing friends and neighbors, and in one case aiding and abetting such killing. Regarding these deaths, little difference exists between the circumstances of these cases and those involving family relationships. Most of these cases involved arguments and altercations that led to mortal wounds.

Women's violence was not restricted to private spaces. Ten women, or 25 percent of those indicted, faced charges for killing in public locations. This contrasts with Shoemaker's study, who found no women charged with murders that took place outdoors, although "16 percent of those committed by women took place on or around doorsteps." accounts for some of the differences between his findings and mine. In my study, seven women were charged with crimes that took place outdoors and three charged with murders in public houses. This suggests that in some of London's roughest areas, such as Catherine-Wheel Alley and Chick Lane, social conventions surrounding appropriate female space, home or work, did not necessarily restrain female behavior.

In nine deaths, women were charged alongside men. It is hard to generalize about these cases as each represents distinctly different circumstances. In one case, OBSP provides no substantive testimony. In other cases, testimony suggests that some women charged were at the scene, but apparently not directly involved in the activities. Other women appear to have been brought before the courts by virtue of their relationship to the victim or other alleged perpetrators, as in the cases of Esbeck Lovedon and Sarah Smith, described above. ${ }^{67}$ Four of the deaths involved altercations. The death of a Bow Street Runner took Hannah Brian and Eleanor Hern to court, along with eight men. ${ }^{68}$ Jane Taylor (also Morgan) faced charges alongside her lover, Sam Taylor, in the murder of Thomas Partridge. A witness at the scene reported that Jane urged the stabbing of the victim during the fight. Sarah Horton recalled Jane yelling, "Damn him, stab him" and commented that "she repeated it seven or eight times." ${ }^{69}$ Getting 
involved in someone else's argument could prove deadly. Walter Flaherty stepped in to stop some sparring between Mary Jordan, her husband and several friends; unfortunately Flaherty became the victim. ${ }^{70}$ Only one of the cases in which men and women were charged together suggests that a man involved himself in an altercation to protect women. Antonio Cordosa stepped in at the request of Sarah Brown and Elizabeth Rogers, two prostitutes involved in a fight with strangers on the street. At trial, his capital conviction suggests the judge viewed him as most responsible for the death. ${ }^{71}$ Given the evidence available in these nine cases, it appears that honor and protection of women did not play a large role in cases when men and women were indicted together.

Difficult relationships account for some of the female homicide indictments, but drugs, alcohol and mental illness often came into play as well. Maria Theresa Phipoe announced at her execution that laudanum played a part in her misdeeds. In court, she testified that she was could not remember many of the circumstances surrounding the attack and said "some woman searched me, and changed my bloody clothes; when I found myself in this situation in the room, the people dressed me, and took me to the hospital, and a little time afterwards, they put a strait waistcoat [straightjacket] on me."72 Alcohol factored into several cases. When Frances Lewis arrived at the home of her brother to inform him that her son had been killed at sea, Lewis argued with her brother's pregnant girlfriend, Ann Rose. Both women were intoxicated. The argument turned to fighting and Rose later died after she miscarried; the grand jury indicted Lewis in both deaths. ${ }^{73}$ A similar case involved Alice Bolus and Jane Collins fighting over a transgression committed by Collins's son who occasionally ran errands for Bolus. Bolus died after the altercation, but her husband, a constable, testified that his wife "was a woman very much given to liquor" and a surgeon further gave evidence that "her life was very precarious." ${ }^{74}$ Mental health issues played a role in one family-related case. Catherine Hughes allegedly killed her sister, Elizabeth Ham. Witnesses raised serious doubts about Hughes' competency at her trial in 1786, alleging she engaged in self-mutilation and "always had a remarkable wild look." 75

Defendants' occupations also played a direct role in charges against seven women. The courts charged two nurses in the deaths of children for whom they were responsible. ${ }^{76}$ One housekeeper, Eleanor Hughes, was charged (along with several other lodgers) with murdering her tenant. A grand jury indicted servant Mary Nott for the murder of a wealthy French lodger in the house she worked. Three rather sensational cases involved servants who attempted to kill or did kill their employers. One of the cases involved fourteen-year-old servant Elizabeth Hinchcliff, charged with attempting to poison her mistress, Ann Parker, and students at Parker's school. Hinchcliff offered little defense at her trial, simply saying "My mistress ill used me." In another case, Eliza Fenning, a cook, allegedly tried to kill her employers by putting arsenic in dumplings. Finally, Henrietta Radbourne (alias Gibbons) was charged with "feloniously and traitorously" murdering her mistress, Hannah Morgan, a wealthy widow. None of the other servants could have been charged with this more severe crime-the two females accused of poisoning did not succeed and Nott did not kill her employer, but rather someone else. ${ }^{77}$

The cases of these forty women tried for murder and related crimes at the Old Bailey supports conclusions of other historians who analyze crime in early 
modern England that women were acquainted, usually intimately, with persons they allegedly killed. Violence was inherent in late eighteenth-century London and perhaps the interpersonal violence here proves more important than the fact that women killed people they knew. Women often had little recourse but to stay in partnerships, no matter how bad they were. Furthermore, the tensions that often went hand-in-hand with the hardships of working class people, women in particular, likely contributed to many the of homicides. As had been demonstrated, often the problems of everyday life-domestic abuse, quarrels over money, alcohol abuse, etc.-boiled over leading to deadly altercations. While women did not move out of their ordinary daily lives to commit these crimes, as demonstrated by their relationships to the victims, and their deeds were not confined to their domiciles or places of work. By virtue of the alleged crimes taking place in public houses and other locations, it is evident that women moved about the city.

\section{Verdicts and Sentencing}

Conviction and sentencing patterns that emerge in these cases also yield valuable information about women's daily activities and societal attitudes towards women. When indicted for violent crimes, women were more likely to be found innocent than guilty. Juries acquitted 46 women (61 percent) and found 29 guilty (39 percent) (Table 4). The number found guilty is a bit misleading, as many were actually found guilty of reduced charges, not the original charges filed against them. In murder-related cases, the courts found 23 women (57 percent) not guilty.

A variety of situations led juries to not guilty decisions, including extenuating circumstances, someone else's confession, or a lack of evidence. As discussed above, the courts found one woman, Catherine Hughes, insane and committed her to St. Luke's asylum. ${ }^{78}$ Regarding the use of insanity defenses, Beattie writes "women . . . probably had a better chance of pleading insanity" than did men. ${ }^{79}$ This point is difficult to prove in these cases as only one woman used the defense. Over the same period, men used the defense more often. The courts found nine men (out of 308 defendants) insane at the time of the murder in question, but some still received guilty verdicts despite their illnesses. ${ }^{80}$ Other acquittals involve different extenuating circumstances. Catherine O'Conolly and John Burk, charged in the death of Elizabeth Colbert, were acquitted when the

Table 4. Female Convictions for Violent Crimes at Old Bailey 1782-1815

\begin{tabular}{lccr}
\hline & innocent & guilty & total \\
\hline murder, attempted murder and petit treason & 21 & 17 & 38 \\
manslaughter & 1 & 0 & 1 \\
aiding and abetting murder & 1 & 0 & 1 \\
newborn child murder & 18 & 6 & 24 \\
misc. violent crimes & 5 & 6 & 11 \\
Totals & 46 & 29 & 75 \\
\hline
\end{tabular}

Source: OBSP, Dec. 1782-Nov. 1815. 
surgeon testified "that fright or passion might have occasioned the death of the deceased." ${ }^{\prime 1}$ In two cases involving nurses, autopsies showed that the two children in question died from illnesses, not murder. ${ }^{82}$ Esbeck Lovedon, accused of killing her daughter, was exonerated was after her lover confessed to the crime. ${ }^{83}$ In this group of cases, juries found all women charged with killing their children not guilty.

Seven women charged with murder and related offenses received capital convictions while juries downgraded murder charges to manslaughter in 10 cases. (See Table 5 for all sentencing.) Controversy over capital punishment grew during the eighteenth century (largely due to the fact that there were over 200 capital offenses on the books), but its application to murder convictions remained in place until the twentieth century because people viewed capital punishment for this crime as both justifiable and appropriate. ${ }^{84}$ Claiming benefit of clergy, a uniquely English plea, was a possibility in manslaughter cases, though not for murder. In the Middle Ages the state struggled to find a means to punish offending clerics without alienating the church. Through the use of this 'benefit,' members of the clergy could not be executed for crimes for which they were found guilty, but were, instead, to be branded to identify them as offenders. Identification of clergy was determined by their ability to read Psalm 51. Men began to memorize the verse and the exclusion from punishment was eventually granted to all men who could recite it. Full use of benefit of clergy was extended to women in statutes during the reigns of William and Mary and Anne. ${ }^{85}$

Occasionally, a person convicted of capital murder received a sentence that included post-mortem dissection, or 'anatomization' as it was termed at the time. ${ }^{86}$ In what judges determined were the most egregious cases of homicide, the state took possession of the body and conveyed it to Surgeon's Hall for dissection as was vividly portrayed in William Hogarth's engraving The Reward of Cruelty. This practice began in 1752 as part of the Murder Act to serve as a deterrent. ${ }^{87}$ Two women in this period, from the sources consulted, were to be anatomized. The Times reported that Eleanor Hughes received that sentence, but she "pleaded pregnancy" after her sentence was delivered to no avail. Henrietta Radbourne, too, was to be anatomized. ${ }^{88}$

What convinced the courts that seven of these women should be found guilty of willful murder or attempted willful murder, and should be sentenced to pay for their crimes with their lives while others should be convicted of manslaughter and receive much lighter sentences? Neither place of birth nor age

Table 5. Sentences for Women Convicted in Homicide and Related Crimes 1782-1815

Number

death by hanging

imprisoned one year or greater

imprisoned $<$ one year + fine

imprisoned $\geq$ one year plus fine

fine only

branded

Total

Source: OBSP, Dec. 1782-Nov. 1815. 
seemed to be mitigating factors in convictions. The lack of birthplace information recorded in OBSP suggests the data ultimately did not concern the court. For the women for whom age is available, the ages are distributed across the categories, including two servants one aged fourteen and another fifty-three. ${ }^{89}$ Apparently youth did not necessarily garner sympathy, at least at this stage of the judicial process.

Of the ten women convicted of manslaughter, nine were convicted in situations in which friends or lovers died during altercations requiring the perpetrators to defend themselves. For example, when Jane Churn ignored her lover James Scofield's question, he called her a "bloody bitch," struck her several times, and the two fell onto the floor, fighting. Churn stood up, grabbed a fork from a nearby table and stabbed him with it. Still angry, she followed him down the stairs and hit an already-downed Scofield with a poker. ${ }^{90}$ Catharine Ryan received a six-month jail sentence for killing her friend Elizabeth Monoghan over a drinking debt. The two women, who lived in the same house, fought for several minutes after Monoghan struck Ryan's face with a poker. Monoghan lived for six weeks after Ryan battered her, but the surgeon believed she died of that strike as it caused an abscess to form on her brain. ${ }^{91}$ As noted previously, Mary Ann Winter's partner abused her; the jury may have been moved by witness accounts of the ill-treatment she received. ${ }^{92}$ Ann Thompson was found guilty of manslaughter for the death of her partner, James Walker, a black sailor. Lord Chief Baron Sir Archibald Macdonald offered the following to the jury after all testimony had been heard:

If you should be of opinion any such scuffle happened between them, and in fact that there was enmity between him and this woman, and the story to be true, and that he had been beating her before-if you believe that to be the case, and that this woman under these circumstances committed this act of violence, although perhaps she might have gone further than she ought to have gone; - in consideration of human infirmities, persons under these circumstances not having their recollection and reason and government of their passions, as in cooler moments they would have it. The law in that case extends the crime to manslaughter only. ${ }^{93}$

Sarah Brown did not know her victim, but the allegations against her also involved an altercation. Brown, a prostitute, stood accused of killing a stranger (Thomas Davies) on the street when he bumped into her and a friend while walking the streets. Her rather light sentence, one year in Newgate jail, suggests that the court viewed the man involved, Antonio Cordosa, to be more culpable; the judge punished him to the fullest extent of the law, sentencing him to hanging and anatomization. ${ }^{94}$ In most other street altercations, the verdicts rendered were manslaughter, which makes Cordosa's sentence unusually harsh, because English judicial practice long upheld a pattern of reduced charges and light sentences in situations where emotion and altercations went hand-in-hand. The fact that Cordosa was Portuguese could have played into the decision made by the jury and the judge. ${ }^{95}$

Women found guilty of manslaughter received jail sentences of varying lengths sometimes accompanied by fines, with two exceptions. Judge Lloyd Lord Kenyon lightly sentenced Jane Churn to a one shilling fine and, Judge James Eyre sentenced Frances Lewis, who claimed clergy, to be burned on the hand. ${ }^{96}$ 
The decisions to downgrade charges in these cases indicates that juries looked upon these women, often abused, with some degree of sympathy and recognized their right to self-defense.

Beattie argues that convictions for willful murder were most prevalent in two types of cases: those that involved the commission of another crime and those "in which malice and deliberation were clear." ${ }^{.97}$ None of the female cases seem to have involved the commission of other crimes, but many of the murders were intentional acts that involved ill-will. Phipoe argued over a watch; Elizabeth Godfry argued with the neighbor who had called the authorities on her; servant Henrietta Radbourne had been asked by her mistress to resign; and servant Mary Nott attacked her victim while he slept. ${ }^{98}$ The two poisonings and two attacks on persons as they slept certainly suggest that the crimes were premeditated.

One demographic commonality was shared by all seven condemned women - they were all unmarried/unpartnered. Elizabeth Godfry recognized her vulnerability during the altercation that brought her to trial, saying, "I have no man to protect me." ${ }^{99}$ Godfry may have been right: juries found most of the women indicted alongside men not guilty or guilty of reduced charges. The exception, Eleanor Hughes, received a capital sentence for killing another lodger. The unmarried Hughes, however, seemed to direct the actions of her male co-conspirator. ${ }^{100}$ The fact that these women were not attached to a man clearly figured in the sentences for their actions.

Occupation also shaped sentencing patterns. Numerous statutes at the time were directed at servants, including laws that specifically outlawed dwelling house theft and embezzlement, along with harsh petit treason statutes that severely punished those who were violent toward their masters or mistresses. Four female servants faced charges for petit treason, homicide or attempted homicide in London and each was capitally convicted, as dictated by law. Eliza Fenning and Elizabeth Hinchcliff attempted to kill their employers by poisoning them with arsenic. ${ }^{101}$ Henrietta Radbourne stabbed her sleeping mistress in the head with a bayonet. Originally charged with petit treason, the jury could not sustain that charge because of a lack of witnesses, but the judge, demonstrating his disgust, sentenced her to anatomization following her hanging. ${ }^{102}$ At a later appeal, Recorder James Adair also expressed horror at her behavior, telling her in court:

Bound to the unfortunate person [Mrs. Hannah Morgan], whose death you have been the instrument of, by every tie of duty and obedience, while you were in her service; and one of those on whom she had a right to depend for protection, you have (instigated by the most wicked motives) in the hour of rest, and when this unfortunate lady was in her own chamber, and in her own bed, where she might expect security from all, and be under the protection of her own family; you have, with murderous intention, availed yourself of an artful means to be introduced into her chamber; where you, or those with whom you have been associated, perpetrated the horrid fact. ${ }^{103}$

The fourth servant was Mary Nott, convicted of killing Count De Gripiere De Laval De Moncroc, a lodger in the house she served, while he slept. ${ }^{104}$ None of the trial testimony of the servants indicates that the murders grew out 
of altercations, although two of the women expressed concerns about unspecific ill treatment.

These four female servants were shown to have operated with malice and they may also have incurred special wrath because of the stealth of their crimes. The harshness of their sentences, however, also depended to some degree on their status as servants. Service created difficult employment situations in which individuals were subservient to those who employed them, but simultaneously part of the family. They surely experienced emotional responses similar to those that emerged in the context of kin relationships, but had little agency. ${ }^{105}$ Such complications could not be recognized, however, for they appeared to challenge the entire hierarchical social structure. ${ }^{106}$ Their violent behaviors required the courts to employ sanctioned, violent discipline in an effort to preserve these structures. ${ }^{107}$

Does Eleanor Hughes, who was not a servant, also fit this model? In some regards, she does. As the keeper of a boarding house, she was supposed to provide a home for those who lodged there. By killing a lodger, she violated those expectations. A former sailor who also lodged with her apparently assisted with the crime, tying the knots that bound their victim's hands during the strangling. Furthermore, Hughes was found in possession of pawnshop receipts, providing evidence that she pawned the victim's clothing. ${ }^{108}$ Not only did she kill, but she compounded her misdeed by stealing from her victim after his death. Each of these five women, the four servants and the housekeeper, violated strongly held ideas about how women employed in various positions should behave and consequently the court convicted them and punished them to the fullest extent of the law.

The convictions of the other two women, Maria Theresa Phipoe and Elizabeth Godfry, highlight other social issues. Both women were involved in fatal altercations. Other women when found guilty in these situations had their charges reduced from willful murder to manslaughter, but circumstances in the lives of these two women may have convinced juries that their behavior had to be dealt with forcefully.

Phipoe had had a previous brush with the law; tried and convicted in 1795, she eventually went free because of a technicality. ${ }^{109}$ It is possible that Elizabeth Godfry had also been in court before. A defendant with the same name appeared at the Old Bailey in November 1805, charged with dwelling house theft. ${ }^{110}$ Both women named Godfry were approximately the same age and both were prostitutes, so it is reasonable to think they were the same person. Regarding both Phipoe and Godfry, the juries might have concluded that since these women had transgressed before, as recidivists they did not deserve reduced convictions. ${ }^{111}$ The altercation in which Godfry was involved had started earlier in the day; this may have convinced the jury that she killed out of retaliation, rather than in a moment of passionate anger. ${ }^{12}$

One additional factor might have contributed to the capital convictions of both women. Elizabeth Godfry was a prostitute and evidence suggests that Maria Theresa Phipoe also plied the trade. Elizabeth Godfry admitted this by stating that that she lived in a "house for women of the town" perhaps as a means to discredit her victim who was living with another prostitute when she attacked him. ${ }^{113}$ Phipoe may actually have been a courtesan rather than a street prostitute. At the time of her trial for murder the Times reported she possessed a 
considerable amount of money: "200£ in ready money, and an annuity of $200 £$ per year." ${ }^{114}$ No family connections were mentioned at trial, which would have been the case had she had high social and economic standing. No prominent character witnesses came forward either, further raising questions about the source of her money. ${ }^{115}$ During her first brush with the law Phipoe was charged with holding John Courtoy (also Cortois) against his will and robbing him of considerable money - £2000. Mary Cox allegedly made reference to this during the fight that preceded her murder, calling Phipoe "Mr. Courtoy's whore." When Courtoy was attacked, a maid assisted Phipoe indicating Phipoe had some money available to hire such an employee. ${ }^{116}$ Published several decades after the trial, The Chronicles of Crime contained a story about Phipoe which claimed: "the prisoner was a person of abandoned character, and that she kept a house, where she was in the habit of receiving visits of a certain character from gentlemen." 117 Such comments, as Tony Henderson notes, express the widespread social disdain for prostitutes, although prostitution itself was not illegal. ${ }^{118}$

If the courts did look negatively upon Godfry and Phipoe because of their trade, this attitude may also be pertinent in the capital conviction of Eleanor Hughes. The writer of a story about her trial alleged that Hughes' home also served as a brothel. ${ }^{119}$ Engaging in prostitution did not automatically condemn a woman accused of murder to death, as the cases of Honour Brown and Sarah Brown demonstrate. When combined with other deviant behavior, however, it likely played a role in capital sentences.

Seven women were capitally convicted, and six were hanged. Although age did not seem to have been an important consideration in convictions, it apparently was taken into consideration after sentencing for Elizabeth Hinchcliff. The account of the trial contains the following: "The prisoner was recommended to mercy on account of her age, and her parents being honest people; and the jury recommended her on account of her age." 120 Thus not only was her youth taken into account, but also the fact she had 'good' parents. Just as some women were treated more leniently because of their relationships with husbands or lovers, in this case her relationship with her parents was taken into account because they could be responsible for her. Her parents likely never cared for her again, however; as a result of a Royal pardon Hinchliff became one of thousands of people sentenced to penal exile in Australia. ${ }^{121}$ In Deborah Oxley's study of transported women in the nineteenth century, she found that occasionally murderers continued to be transported to Australia. ${ }^{122}$ Mary Nott's story did not end with her execution. Following her death, someone else, "a foreigner" was arrested and confessed to the crime: this unnamed person was alleged to have said that Mary had been involved in the death of the Count but had not murdered him. Many newspaper articles dismissed her execution, saying "in murder all accessaries [sic] are held in law to be principals." 123 This might be the law, but other cases have shown that women when accused alongside men seldom faced execution; instead, principals of discretion and marital coercion were applied allowing for milder sentencing. While it is impossible to know what may have happened if the unnamed perpetrator had been arrested with Nott, it is easy to surmise that her life might have been spared. 


\section{Conclusion}

What do these trials involving women and murder tell us about women in the metropolis and in English society more broadly? The inquiry into these lives serves as a confirmation of the findings made by other historians of violent female criminality in the long eighteenth century. As Beattie found in his study of Surrey and Sussex, as well as Durston and Shoemaker in their longitudinal studies of women and murder in the eighteenth century, women almost exclusively were charged with the killing of people they interacted with regularly: family, friends and those known through work. ${ }^{124}$ What is important, though, is the difference found in this examination with that of Shoemaker's findings in terms of locations of the alleged offenses. One has to consider, that over this time period marked by war, that women may have enjoyed a greater freedom of movement.

In The Hanging Tree, V.A.C. Gatrell argues, "the weaker sex became a vehicle through which men registered their potency, benevolence, and chivalric selves." 125 In convictions handed down to women this point certainly applies. The use of discretion through the reduction of many murder charges to manslaughter indicates that judges and juries understood that women led lives constrained by societal norms which dictated that they be under the protection of men and they, too, understood that sometimes that emotional responses to difficult circumstances occasionally led to disaster. In this way, the courts demonstrated "benevolence and chivalr[y]" as well as their willingness to sanction violence carried out by these women, recognizing that sometimes life left many of them with few options but to defend themselves in ways men would. Those who were treated most harshly, receiving capital sentences for the commission of willful murder and attempted murder, violated several firmly held expectations for females. In these cases, the court exercised its "potency."

First, all of the women who were sentenced to die defied gender roles as understood by society. They had no husbands or partners and none were living with their parents during the time of their crimes. Working class women were expected to attend to their daily lives in a fashion that did not attract attention. This meant that they were to go quietly about their business and behave obediently to those who supervised them. Prostitutes further defied norms by eschewing marital expectations and remaining independent of male guardianship.

Other forms of gender expectations factored into some cases as well. The Complete Newgate Calendar's account of Phipoe's transgressions suggests that her behavior was "masculine," not an unusual description of a woman who employed manly traits such as force or violence. ${ }^{126}$ Phipoe had not been indicted for offenses involving a husband or lover, but killed a friend in a laudanum-fueled fight. The description of Phipoe as masculine provides an interesting juxtaposition, because the courts sanctioned some masculine behavior as demonstrated by the light sentences several women received when convicted of manslaughter in offences of the heart combined with self-defense. If a woman behaved in a masculine fashion, masculine punishment must have seemed reasonable to judges when the case did not involve domestic abuse. In these instances, the court, like the women convicted of manslaughter, were the ones who were sanctioned to react violently. 
While some perceived her actions as masculine, Phipoe attempted, unsuccessfully, to use gender norms as a defense. She understood the court's tendency for sympathy towards emotional females when she exclaimed at the scene that her passion had gotten the best of her; witnesses substantiated this in court stating Phipoe was a "rather passionate" person. ${ }^{127}$ Attempting to rationalize her behavior, she sought to demonstrate that she was, in fact, a weak female subject to such outbursts. ${ }^{128}$ In 1808, Lord Chief Baron McDonald admitted that passion in a heated moment may cause a person to act out in emotional ways. ${ }^{129}$ Many may have also considered Eleanor Hughes masculine through her actions, yet she also attempted to use her femininity to escape capital punishment. Following her verdict, she unsuccessfully claimed she was pregnant. Godfry employed the same method when she told the court she had no male protector.

Second, work also played a role in sentencing decisions. This is certainly true for the servants. They broke not only the law, but they also broke a nearly sacred bond of trust between servant and master when they murdered or attempted to murder people under their care. Recorder Adair reminded admonished Radbourne at trial saying she was "[b]ound... by every tie of duty and obedience, while you were in her service; and [was] one of those on whom she [Mrs. Morgan] had a right to depend for protection"130 The four domestic servants and the one housekeeper engaged in 'female' occupations, but their activities did not comport with societal expectations of women who carried out those occupations. The public expected female servants to be helpful and willing to serve-obedient; they did not expect them to attempt to seize authority for themselves through aggressive behavior such as attacking employers while they slept or poisoning the household's food. Again, though, discretion came into play in the eventual transportation of fourteen-year-old servant Elizabeth Hinchcliff. Whether it was because her victims did not die, her youth or her respectable parents, the justice system, through the use of a Royal pardon, found reason to not take her life. Prostitutes, too, needed to be quiet about their work, not drawing attention to themselves or their actions. In other words, women who acted outside of gendered expectations could anticipate that the courts would sentence them to the fullest extent of the law. The fact that there was no one other than themselves to answer for their behavior may have furthered that likelihood.

Finally, and not surprisingly, recidivism, as demonstrated by Phipoe and Godfry, likely played an important role in sentencing decisions. As Beattie points out, character was extremely important in the sentencing stage. ${ }^{131}$ If it could be demonstrated that an individual had offended previously then character was diminished, perhaps irreparably. Phipoe brought character witnesses with her to court and they spoke neutrally or positively. Her previous crime, however, could not have gone unnoticed by the court. She made reference to it at trial and the earlier case received substantial press. Godfry, on the other hand, had no one to testify for her character; furthermore, she identified herself as a prostitute and admitted she lived in dwelling that housed other prostitutes. Women of such low character could expect harsh sentences.

Juries and judges showed their "benevolence" and "chivalry" when they downgraded charges or called for pardons when deemed necessary. Judges showed their "potency" when they enforced the capital code to its fullest extent. Execution was called for only when unattached women demonstrated that they 
could not be trusted to handle their own behavior as a means to ensure that the social order was reinforced.

\section{Endnotes}

Thanks to several colleagues who read earlier versions of this article: Josh Adair, Martin Battle, Stephanie Carpenter, Terry Strieter and Merry Wiesner-Hanks. Thanks also to research assistants Daniel Albert, Erin Ragsdale and Jamie Booth. All mistakes within are my own. Address correspondence to Kathy Callahan, Department of History, Faculty Hall 6B, Murray State University, Murray, KY 42071. Email: kcallahan@murraystate.edu.

1. The Times [London], December 11, 1797, 2.

2. For work on crowds see, for example, V.A.C. Gatrell, The Hanging Tree: Execution and the English People 1770-1868 (Oxford, 1994), chapters 3 and 8.

3. The Proceedings of the King's Commission of Peace, Oyer and Terminer and Gaol Delivery for the City of London and Gaol Delivery for the County of Middlesex (known henceforth as OBSP), 1797-98, case 8.

4. The Times, December 8, 1797 and Annual Register, 1797, 152-55. At her trial Phipoe attempted to tell a different story, claiming that she had no recollection of attacking Cox. Phipoe had been tried before. In 1794 she faced charges for and was found guilty of robbery, but after a retrial she went free. See OBSP, 1794-95, case 268 and 1795-96, case 189 .

5. J.M. Beattie, "The Criminality of Women in Eighteenth-Century England," Journal of Social History 8 (1975): 96.

6. Peter King, Crime, Justice, and Discretion in England, 1740-1820 (Oxford, 2000).

7. Kathy Callahan, Women, Crime and Work: The Case of London 1783-1815 (unpublished $\mathrm{PhD}$ dissertation, Marquette University, 2005).

8. King, in Crime, Justice, and Discretion; and Deirdre Palk, Gender, Crime and Judicial Discretion, 1780-1830 (Woodbridge, 2006) focus exclusively on illegal appropriation. J.M. Beattie, Crime and the Courts in England, 1660-1800 (Princeton, 1986), 77-139 covers property and violent crimes in-depth, but there is considerably less information about women except in infanticide cases.

9. Beattie, Crime and the Courts, 243.

10. Douglas Hay, in "War, Dearth and Theft in the Eighteenth Century: The Record of the English Courts," Past and Present, 95 (May 1982) uses similar periodization.

11. OBSP and The National Archives (NA), Home Office Papers, HO-26 series.

12. Summary, not felony, courts heard the greatest number of assault cases, for example. See Drew D. Grey, Crime, Prosecution and Social Relations: The Summary Courts of the City of London in the Late Eighteenth Century (London, 2009), 92-94.

13. Callahan, Women, Work and Crime, 140.

14. An examination of the distribution of these crimes over the entire period does not yield additional information as they occurred with some evenness. Indictments were highest in 1795 (six), followed by 1815 and 1808 (five each), several years had no indictments: $1788,1790,1794$, and 1796 . These differences are more likely related to evidence at hand rather than a comment on any particular year being more violent; a thorough understanding of actual frequency of violent crime requires at the least an investigation into available coroners' records and cases brought before the summary courts as well as those not advanced by grand juries. 
15. For example, see Beattie, Crime and the Courts, 113-24; Lionel Rose, The Massacre of the Innocents: Infanticide in Britain 1800-1939 (London, 1986); and Mark Jackson, New-born Child Murder: Women, Illegitimacy and the Courts in Eighteenth Century England (Manchester, 1996).

16. For the early modern period, see Garthine Walker, Crime, Gender and Social Order in Early Modern Europe (Cambridge, 2003), especially chapters 2-4. For the modern period, see Margaret Arnot and Cornelie Usborne, eds., Gender and Crime in Modern Europe (London, 1999), especially 1-44.

17. Julius Ruff, Violence in Early Modern Europe 1500-1800 (Cambridge, 2001), 117-59 and Robert Shoemaker, "Male Honour and the Decline of Public Violence in Eighteenth-Century London," Social History, 26, no. 2 (2001): 203-4.

18. Callahan, Women, Work and Crime, 339-41.

19. Gregory Durston, Victims and Viragos: Metropolitan Women, Crime and the Eighteenth-Century Justice System (Suffolk, UK, 2007), 61.

20. Beattie, Crime and the Courts, 97; Ruff, Violence, 121-24; and Shoemaker, "Male Honour," 199.

21. Shoemaker, "Male Honour," 199-200.

22. Studies of criminality for this period in England have tended to focus on property crimes; see note 7. Beattie, in Crime and the Courts, 77-139 covers property and violent crimes in-depth, but there is considerably less information about women except in infanticide cases; J.A. Sharpe, "Domestic Homicide," 29-48; J.S. Cockburn, "Patterns of Violence in English Society: Homicide in Kent 1560-1985," Past and Present 130 (February 1991): 70-106 found similar trends.

23. Clive Emsley, Hard Men: Violence in England since 1750 (London, 2005).

24. See, for example, Margaret Hunt, "Wife Beating, Domesticity and Women's Independence in Eighteenth-Century England,' Gender and History, 4, no. 1 (1992): 10-33 and Susan Dwyer Amussen, "Punishment, Discipline, and Power: The Social Meanings of Violence in Early Modern England," Journal of British Studies, 34 (January 1995): 70-89. For domestic violence in Victorian England, see, for example, Shani d'Cruze, Crimes of Outrage: Sex, Violence and Victorian Working Women (DeKalb, IL, 1998).

25. Beattie, Crime and the Courts; V.A.C. Gatrell, The Hanging Tree; Peter Linebaugh, The London Hanged: Crime and Civil Society in the Eighteenth Century (Cambridge, 1992); Deborah Oxley, Convict Maids: The Forced Migration of Women to Australia (Cambridge, 1996).

26. Durston, Victims and Viragos, 55-80.

27. Carolyn Conley, Certain Other Countries: Homicide Gender, and National Identity in Late Nineteenth-Century England, Ireland, Scotland, and Wales (Columbus, OH, 2007). For more on the nineteenth century see: Lucia Zedner, Women, Crime and Custody in Victorian England (Oxford, 1991) and Judith Knelman, Twisting in the Wind: the Murderess and the English Press (Toronto, 1998).

28. Louise Tilly and Joan Scott, Women, Work and Family (New York, 1989), 3 and 31.

29. Bridget Hill, Servants: English Domestics in the Eighteenth Century (Oxford, 1996) 3-4, 39-42. See also Peter King, "Female Offenders: Work and Life Cycle Change in Late-Eighteenth Century London," Continuity and Change 11, no. 1 (1996): 71 and 76 for analysis of employment problems, including service, in the city. 
30. Clive Emsley, Crime and Society in England, 1750-1900, $2^{\text {nd }}$ ed. (New York, 1996), 41-44; see also Beattie Crime and the Courts, 80-81. Ruff in, Violence, 120, points out that murder indictments are not the place to look for the overall murder rates in any city. Problematic for this period is the lack of extant coroners' reports.

31. OBSP, 1795-96, case 392.

32. See Beattie, Crime and the Courts, 77-96 for a detailed analysis of the types of murder charges.

33. Beattie, Crime and the Courts, 80-81.

34. William Blackstone, Commentaries on the Laws of England, vol. 4 (London: 1769; reprint, Chicago, 1979), 203-4.

35. Peter C. Hoffer and N.E.H. Hull. Murdering Mothers: Infanticide in England and New England (Manchester, 1981), 75-79. This decline was part of long-term phenomenon that began in the early seventeenth century. See also Shoemaker, "Male Honour," 191.

36. Beattie, Crime and the Courts, 107-12. See especially Table 3.4; Beattie discusses changing attitudes towards violence, 133-39. Also see Shoemaker, "Male Honour," 190_ 208 and Forbes, "Deadly Parents," Journal of the History of Medicine and Allied Sciences, 41 (1986): 177. For a comprehensive look at historical changes in behavior that likely contributed to the falling rate of murder (and physical violence, in general), see Norbert Elias, The Civilizing Process, trans. Edmund Jephcott (Cambridge, MA, 2000).

37. See Ruff, Violence, 117; Beattie, Crime and the Courts, 98; Beattie, Policing and Prosecution, 373. For information on the criminal biography see Philip Rawlings, Drunks, Whores and Idle Apprentices: Criminal Biographies of the Eighteenth Century (London, 1992), 1-35; and Gatrell, The Hanging Tree, 113-19. For newspapers see, Peter King, "Newspaper Reporting and Attitudes to Crime and Justice in Late-Eighteenth- and Early-Nineteenth Century London," Continuity and Change 22, no. 1 (2007): 73-112.

38. Titled men were executed by beheading with a sword.

39. OBSP, 1812-13, case 580.

40. Callahan, Women, Work and Crime, 140.

41. Shoemaker, "Male Honour," 202.

42. OBSP, 1783-84, case 777 and case 972.

43. See for example OBSP, 1803-4, case 356 in which Humphry Hobart faces charges for killing Thomas O'Reilly during an apparent duel. In another case, James Connop was charged with killing James Lewis during a fight resulting from an argument over whose home county was the best-Worcester or Herefordshire. OBSP, 1800-01, case 561. Shoemaker, "Male Honour," 193ff.

44. OBSP, 1783-84, case 326. Durston, however, did find several cases in which mistresses committed murder in the first seventy-five years of the eighteenth century; see Victims and Viragos, 72-74.

45. Sharpe, "Domestic Homicide," 38; Cockburn, "Patterns of Violence," 97-98.

46. OBSP, 1804-5, case 326.

47. Callahan, Women, Crime and Work, 106.

48. Shoemaker, "Male Honour," 196. For a detailed explanation of discretion see Peter King, Crime, Justice and Discretion, 1-14. Zedner, in Women, Crime, and Custody, 38 writes that discretion possibly skewed female property indictments so much so that 
murder rates may provide "a better indication of 'actual' levels of crime than any other offence."

49. See, for example, Roger Swift, "Crime and the Irish in Nineteenth-Century Britain," in The Irish in Britain 1815-1939, eds. Roger Swift and Sheridan Gilley (Savage, 1989), 163-64; King, "Female Offenders," 71; and M. Dorothy George, London Life in the Eighteenth Century, $3^{\text {rd }}$ ed. (New York, 1951), 117-45.

50. Callahan, Women, Crime and Work, 116.

51. OBSP, 1798-99, case 284.

52. Shoemaker, "Male Honour," 196. In Beattie's study of Surrey and Sussex, married women actually outnumbered unmarried women in accusations of violent crimes; see "The Criminality of Women," 102. The fact that this proportion is higher than that in my study likely reflects a large number of assault cases, which are largely absent from the Old Bailey courts.

53. Callahan, Women, Crime and Work, 125.

54. Emsley, Crime and Society, 44; Beattie, Crime and the Courts, 99. Beattie, in "The Criminality of Women," 83, specifically discusses the infrequency of females accused of stranger murder.

55. Sharpe, "Domestic Homicide," 29-48. See also Beattie, Crime and the Courts, 106 and Walker, Crime, Gender, and Social Order, 135.

56. Sir Leon Radzinowicz, A History of English Criminal Law and Its Administration from 1750, 1 (London, 1948), 209-13.

57. OBSP, 1811-12, case 6.

58. OBSP, 1809-10, case 432.

59. OBSP, 1797-98, case 456.

60. See Sharpe, "Domestic Homicide," 29-48; Susan Dwyer Amussen, "'Being Stirred to Much Unquietness': Violence and Domestic Violence in Early Modern England," Journal of Women's History, 6, no. 2 (1994): 70-89; and Amussen, "Punishment, Discipline, and Power," 32. A number of OBSP cases filed against men indicated that wives died as a result of abuse. See for example: $1783-84$, case 388; 1788-89, case 98; 1790-91, case 1.

61. OBSP, 1807-08, case 491.

62. OBSP, 1789-1790, case 343.

63. OBSP $1787-88$, case 583

64. OBSP, 1812-13, case 367. Michael Ignatieff writes extensively about Thomas Aris, the administrator of Coldbath Fields, a correctional facility in London for vagrants and petty offenders. Aris himself had a reputation for dishonesty and his son was reputed to be, according to Ignatieff, "sleeping with some of the female inmates." See A Just Measure of Pain: The Penitentiary in the Industrial Revolution 1750-1850 (New York, 1978), 12728, 139. It is impossible to decipher from OBSP as to whether this case involves the father or the son. Ignatieff does not indicate that the illicit relationships with inmates may have led to murder, a topic that needs examination.

65. OBSP, 1797-98, case 246. The editors of OBSP categorized this crime as infanticide, but the circumstances did not warrant that charge: the child was not a newborn and there was no evidence that Champion attempted to conceal her pregnancy or the child's birth. Believing this to be in error, I re-categorized it as a murder. 
66. Shoemaker, "Male Honour," 192, 200, 203. Here, Shoemaker analyzes murder indictments between 1690 and 1791 in ten-year increments. On page 192 Shoemaker writes there were 118 murders in his sample and 93 percent were men, suggesting that approximately eight women were in his sample.

67. OBSP, 1789-90, case 343 and 1807-8, case 491.

68. OBSP, 1798-99, case 284.

69. OBSP, 1791-92, case 100.

70. OBSP, 1808-9, case 673.

71. OBSP, 1810-11, case 131.

72. The Times, 11 December 1797, 2. OBSP, 1797-98, case 8.

73. OBSP, 1785-86, cases 402 and 403.

74. OBSP, 1813-14, case 757.

75. OBSP, 1785-86, case 644.

76. OBSP, 1789-90, case 355 and 1-4, case 397.

77. OBSP, 1795-96, case 392, Hughes; OBSP, 1795-96, case 390, Nott; OBSP, 1809-10, case 664, Hinchcliff; OBSP, 1814-15, case 441. Fenning; and OBSP, 1786-87, case 556. Radbourne.

78. OBSP, 1785-86, case 644.

79. Beattie, Crime and the Courts, 85 .

80. Callahan, Women, Crime and Work, 272. This is, of course, only the number of cases that came to trial. Others with mental illnesses may have been dismissed by coroners or grand juries.

81. OBSP, 1802-3, case 587.

82. OBSP, 1798-90, case 355 and 1802-3, case 397.

83. OBSP, 1789-90, case 343.

84. Beattie, Crime and the Courts, 77.

85. Hoffer and. Hull, Murdering Mothers, 78. Beattie, Crime and the Courts, 77, n. 4. On the laws, see William Blackstone, Commentaries, 4: 363. 5 Anne, c. 6, clergy was given upon request-no reading of Psalm 51 was required.

86. The Times, June 27, 1785, 3 and OBSP, Session 1, 1787-88. I can find no record of Maria Theresa Phipoe being anatomized, but according to G.T.Crooke, ed., The Complete Newgate Calendar, 4 (London, 1926), 228, she was "publicly exhibited" after execution.

87. 25 George II, c. 37. Peter Linebaugh, "The Tyburn Riot against the Surgeons," in Douglas Hay et al, Albion's Fatal Tree: Crime and Society in Eighteenth-Century England (New York, 1975), 76-78. See also Beattie, Crime and the Courts, 525-30 and Gatrell, The Hanging Tree, 81-89 and 255-58.

88. The Times, June 27, 1796, 3, and OBSP, Session 1, 1787-88.

89. Mary Nott was 53. OBSP, 1795-96, 390.

90. OBSP, 1795-96, case 261.

91. OBSP, 1804-5, case 553. 
92. OBSP, 1797-98, case 456.

93. OBSP, 1807-8, case 100.

94. OBSP, 1810-11, case 131.

95. OBSP, 1782-83, case 73. See Beattie, Crime and the Courts, 91-95 on the tradition of reduced charges.

96. OBSP, 1785-86, cases 402.

97. Beattie, Crime and the Courts, 97.

98. OBSP, 1797-98, case $8 ; 1806-7$, case $175 ; 1786-87$, case 556 ; and $1795-96$, case 390.

99. OBSP, 1806-7, case 175.

100. OBSP, 1795-96, case 392

101. The case of Eliza Fenning has been examined by Gatrell in The Hanging Tree, especially 339-70. According to his investigation, many persons in London thought she was unjustly convicted. Because of this, contemporaries worked to demonstrate problems with murder statutes, as well as problems with her case. Gatrell argues that these efforts contributed to major changes in capital punishment later in the nineteenth century. See also Crooke, ed., Newgate Calendar, 5: 159-64 for an eighteenth-century source. For Hinchcliff, see OBSP, 1809-10, case 664.

102. OBSP, 1786-87, case 556. Frank McLynn, in, Crime and Punishment in Eighteenth-Century England (London, 1989), 124 and Dolan, Dangerous Familiars, 238 argue that, as the eighteenth century drew to a close, petit treason was seldom used by the courts.

103. This quotation comes from an appeal related to the case. Her execution was delayed by the court to check the legality of some of the aspects of the trial and its outcome. These supplemental records appear December 12, 1787 in OBSP.

104. See McLynn and his comments on the Nott case, Crime and Punishment, 123. Some of his details on that case are inconsistent with what I have found. His source was the New Newgate Calendar, (London, 1818) and he cited Nott's age as being 63, whereas my source OBSP, 1795-96, case 390, describes her as 53, as does the Times, June 23, 1796, 3. Furthermore, both of my sources spell her name "Nott", while McLynn spells it "Knott."

105. Walker, Crime, Gender, and Social Order, 143-48. Here, Walker speaks specifically of poisoning.

106. Malcolm Gaskill, Crime and Mentalities in Early Modern England (Cambridge, 2000), 210, 307; Dolan, Dangerous Familiars, 65-67.

107. Walker, Crime, Gender, and Social Order, 40, 49; Amussen, "Punishment, Discipline and Power," 4, 10,12; both of these works are particularly insightful on the questions of murder, power, citizens, and the state.

108. OBSP, 1795-96, case 392.

109. OBSP, 1794-95, case 268 and 1795-96, case 175.

110. She was charged, along with two other prostitutes, with the theft of $£ 22$ from James Rough and found not guilty. OBSP, 1804-05, case 684 and HO 26-11 and HO-26-13.

111. See McLynn on this point regarding Phipoe, Crime and Punishment, 123. Again, our sources differ on several points in Phipoe's case, as it did in Nott's. 
112. See Beattie on this point, Crime and the Courts, 95.

113. OBSP, 1806-7, case 175.

114. The Times, December 11, 1797.

115. According to this broadsheet account of her scaffold speech, Phipoe was born in France to "respectable" parents. This information does not appear in print elsewhere, leaving even more questions about her. The last dying speech and confession, Birth, Parentage, and Behaviour, of Mary Benson, alias Maria Theresa Phipoe, who was executed this morning facing the debtor's door, Newgate, and the extraordinary speech she made while she was standing under the gallows. (London: 1795?) Eighteenth Century Collections Online. Gale. History Society Trial, http://find.galegroup.com/ecco/infomark.do?\&source=gale\& prodId $=$ ECCO $\&$ userGroupName $=$ hsociety $\&$ tabID $=$ T00 $1 \&$ docId $=C W 102669031 \&$ type $=$ multipage $\&$ contentSet $=$ ECCOArticles $\&$ version $=1.0 \&$ docLevel $=$ FASCIMILE (accessed March 13, 2012).

116. OBSP, 1794-95, case 268.

117. Camden Pelham, The Chronicles of Crime or, The New Newgate Calendar, vol. 1. (1840; reprint London, 1891), 358, Google Books, http://books.google.com/books? $\mathrm{id}=\mathrm{qzL} 9 \mathrm{rTw}$ XJVEC\&printsec $=$ frontcover $\# \mathrm{v}=$ onepage $\& \mathrm{q} \& \mathrm{f}=$ false $($ accessed September 2 , 2011).

118. Tony Henderson, Disorderly Women in Eighteenth-Century London, London, 1999), $122-28$.

119. The Gentleman's Magazine and Historical Chronicle for the year 1796, vol. 66, part 2 (London, 1796), 696.

120. OBSP, 1809-10, case 664.

121. Hinchcliff departed for Australia on May 9, 1812. Convict Records, http://www. convictrecords.com.au/convicts/hinchcliff/elizabeth/91650 (accessed September 23, 2011).

122. Oxley, Convict Women, 43.

123. Oracle and Public Advertiser (London, England), August 27, 1796; Issue 19:411. Gale. $17^{\text {th }}-18^{\text {th }}$ Century Burney Collection Newspapers, http://www.galetrials.com/products. aspx?pid $=2599 \&$ marketID $=2 \&$ trialID $=29672 \&$ contactID $=65841$ (accessed March 16, 2012). For other papers, see, for example, Lloyd's Evening Post, (London), August 26-29, 1796. Gale. $17^{\text {th }}-18^{\text {th }}$ Century Burney Collection Newspapers, http://www.galetrials.com/ products.aspx?pid $=2599 \&$ marketID $=2 \&$ trialID $=29672 \&$ contactID $=65841$ (accessed March 16, 2012.)

124. Beattie, "Criminality of Women," 83-84 and Crime and the Courts, 106; Shoemaker, "Male Honour," 206; Durston, Victims and Viragos, 67.

125. Gatrell, The Hanging Tree, 336.

126. Crooke, ed., Newgate Calendar, 4: 225 and Durston, Victims and Viragos, 65.

127. OBSP, 1797-98, case 8.

128. The Times, December 8, 1797 and Annual Register 1797, 152-55.

129. OBSP, 1807-8, case 100.

130. OBSP, December 12, 1787, supplemental record.

131. Beattie, Crime and the Courts, 439-46. 